\title{
Forests for Food Security and Livelihood Sustainability: Policy Problems and Opportunities for Small Farmers in Nepal ${ }^{1}$
}

\author{
Bhubaneswor Dhakal ${ }^{2}$, Hugh Bigsby, and Ross Cullen \\ Faculty of Commerce, Lincoln University, Canterbury, New Zealand
}

\begin{abstract}
In Nepal, many rural households need access to public forest resources to complement private resources for food and livestock production. However, current forest policies are largely directed at Environmental protection. The first part of this study identified the effect of current forest policy on livestock production using survey data from 259 households in three Nepal hill districts. The second part used a forestry-agriculture integrated model to examine alternative land use policies that could increase household livestock holdings and income while maintaining the environmental services of the community forest. The results show that current forest policies contributed to reductions in potential household livestock holdings by $34 \%$ for goats, $30 \%$ for cattle and $27 \%$ for buffalo. This exacerbated problems of farm fertility and food shortages in vulnerable and poor households. Modeling of alternative policy scenarios indicates that livestock holdings and income could both be increased for most households in communities practicing agroforestry while still maintaining environmental protection. The increase could be highest for the poorest households. Finally, the article discusses potential implications of new environmental policies on local food security and sustainability in the country.
\end{abstract}

KEYWORDS: Policy, community forest, food security, household income, integrated model

\footnotetext{
${ }^{1}$ This is a preprint of an article whose final and definitive form has been published in the Journal of Sustainable Agriculture [20II] [copyright Taylor \& Francis]; Journal of Sustainable Agriculture is available online at: http://www.informaworld.com/smpp/ with the open URL of your article. You are allowed to use the article by following the terms and condition stated on the website: http://www.tandf.co.uk/journals/pdf/copyright-author-rights.pdf

${ }^{2}$ E-mail address correspondence to authors Bhubaneswor Dhakal, bhubaneswordhakal@gmail.com
} 


\section{INTRODUCTION}

Livestock play an important role in local food security in developing countries. In addition to providing food directly in the form of milk and meat, livestock also provide important services such as power for ploughing and food transportation (Mahat et al., 1987). Farm manures are often the sole means of soil fertilization in areas that are remote from roads, and where farmers are unable to afford fertilizer (Pilbeam et al., 2000; Paudel, 1992; NPC, 2003). Livestock are often the main source of income to purchase market goods including food, and they provide a means of farming business diversification and a hedge against risk (Fafchamps and Shilpi, 2003). Livestock generally contribute a greater share of total household income for poorer households compared to richer ones. Overall, livestock provide a hedge against starvation and extreme poverty, particularly for isolated mountain communities (Riethmuller, 2003).

Public forests have special importance for livestock farming and livelihoods for mountain people in Nepal. Historically, land areas demanding less labor for terracing and suitable for crop production were privatized. Less productive and environmentally sensitive lands were managed as public or communal property for production of multiple products and services (firewood, fodder, pasture, timber, leaf litter, and other non-timber products). As a result, almost all Nepali farmers have no private pastureland. Instead, the farmers graze livestock in forests, or tree limbs are lopped during seasons of animal feed deficits (Graner, 1997; Ives and Messerli, 1989). In addition, about 10 percent of Nepal's land area is alpine pasture. Farmers in high mountain region feed livestock on alpine pasture during the summer season and, move the animal to lower hill forests during the winter (Bhatta, 2002; Graner, 1997; Metz, 1994; Mahat et al., 1987). The mobile herds would contribute to farm fertilization during the winter season. With this system, households with marginal landholdings were able to manage their livestock and maintain food 
security. These agro-ecological conditions have long motivated mountain people to maintain some areas of public forest in every community.

A lot of changes have occurred in Nepal's forestry sector since the political change of the 1950s. The government introduced the Private Forest Nationalization Act of 1956, which consolidated forest management authority to government officers, leading to a complete breakdown in the traditional management regime (Hobley, 1996). The political change also boosted public infrastructure construction and urban development and increased demand for wood nationwide (Hobley, 1996). The breakdown of the traditional management regime and growing demand for wood led to large amounts of deforestation, which coincided with heavy rainfall, landslides and flooding in lower areas including Bangladesh in the 1970s and 1980s (Ives and Messerli, 1989). The mountain farming system, especially the livestock component, was identified as the main culprit behind the degradation of mountain forests. Policy makers determined that, "[t]he main causes of forest degradation are overcutting of wood for fuel and heavy lopping of trees for fodder” (Master Plan Main Report, 1988: p. 31).

Reforestation of community pastureland and "reducing and controlling livestock numbers" to levels manageable with farm resources were considered to be solutions to the problem (Master Plan, 1988, p.148). The community forestry development program was implemented according to the policy guidelines (Edmonds, 2003; Hobley, 1996). In principle, community forestry transfers management responsibility to local communities, allowing them to make decisions appropriate to the community and to capture the benefits of their decisions. In practice afforestations occurred in community pasturelands. Livestock grazing and controlled forest collection were restricted (Dhakal et al., 2005; Bhatta 2000). The government also introduced the Forest Amendment Act in 1998 and a mandatory forest inventory introduced to regulate forest uses and contribute to global environmental conservation, including global climate change 
mitigation as directed by "Sustainable Forestry" in Agenda 21. The policy has dictated compulsory forest inventories and limited forest harvesting to less than $30 \%$ of mean annual increment (MAI) for slow growing species and $60 \%$ of MAI for fast growing species ${ }^{3}$ (Community Forestry Inventory Guidelines, 2000). A number of studies have shown that community forestry policies have been successful in Nepal, including controlling the misuse of public forests, restoration of forest cover and protection of some conservation species (Shrestha et al., 2010; Adhikari et al., 2007; Gautam et al., 2002). The policy increased forest crown cover but has suppressed understory growth of valuable plants used for fodder.

In practice though, the community forestry approach has had undesirable effects on incomes and poverty alleviation. Moreover, a number of studies have reported that a policy focus on environmental protection has led to an overstock and underutilization of community forest resources (Khanal, 2002; Gautam et al., 2002). There have also been problems in terms of social and economic development (Dhakal and Bhatta 2009; Thoms, 2008).

One particular effect of the environmental focus of forest policies is on local food security and livelihoods where there are livestock-based food systems as in Nepal. The present situation is that average private landholdings are less than 0.8 hectares per household. The bottom $47 \%$ of land-owning households have a land area of 0.5 hectares or less, and $29 \%$ of farming households are landless (CBS, 2003; UNDP, 2005). More than $60 \%$ of farming households have a food deficit from their own land (CBS, 2003). Reduced subsidies and rising prices have severely reduced the use of fertilizer (SDC-Helvetas, 2009; CBS, 2008; NRB, 2004; World Bank, 2004). Imported livestock has been growing as illustrated in Appendix Table A1 for the period 1987/88 to $2002 / 3$. Local food security issues have beenincreasing and starvation problems have become

\footnotetext{
${ }^{3}$ At the time of this study the Government amended the Guidelines for Inventory of Community Forests (DOF, 2000) and relaxed community forest harvest by a further $10 \%$ of MAI.
} 
worse in remote districts (FAO, 2008; Gautam, 2009) where the livestock economy and transhumance practices have been severely affected by the conservation policies (Bhatta,2002). The incidence of epidemic diseases and deaths ${ }^{4}$ among poor and malnourished people has increased in institutionally disadvantaged food deficit areas in recent years (Gautam, 2009). In the process of the Tenth National Plan preparation, farmers who suffered from the conservation policies demanded access to forestland grazing and fodder production (NPC, 2003). Instead of responding to the demands of farmers, the government has followed even more stringent environmental policies. For example, Nepal has been selected to participate in the first phase of the Reduced Emissions from Deforestation and Forest Degradation (REDD) project. Protected area increased from $7 \%$ in 1988 to $20 \%$ in 2008 (CBS, 2008; Master plan, 1988) and included many forests used by communities (Muller-Böker and Kolmar, 2000). At the Climate Change Summit in Copenhagen in 2009 the Nepalese government declared the expansion of protected areas from 20 to $25 \%$ of the national area in food-deficit and remote localities as a national commitment to global climate change mitigation and biodiversity conservation (Nepal Monitor, 2009). Public forests have an increasingly important role in Nepal, yet the environmental focus of current policies is limiting the ability of local forests to promote food security, increase incomes and alleviate poverty.

The impact of tradeoffs between environmental conservation policies and community use of forests is potentially more critical where farm animals are the engine of rural economies and livelihoods. The severity of recently introduced environmental policies and programs on food security and livelihoods is not well understood. While a number of studies have attempted to study the impact of forest policy on food security, these studies often limit their scope to an assessment of impacts on household livestock holdings (Adhikari et al., 2007; Dhakal et al.,

\footnotetext{
${ }^{4}$ For example, over 450 people died and hundreds of people suffered from epidemic diarrhoea due to low quality food distributed by the World Food program during July and August of 2009 (Gautam, 2009).
} 
2005; Richards et al., 2003; Fox, 1993). From a development policy prospective the more important question is whether it is possible to reconcile conservation objectives and food security and income needs through alternative policies for community-based resource management. Analysis of this broader question requires a framework that can incorporate the interaction of community forest resources with local economies, and the effect of national forest policies on community forest management.

One framework for studying the effect of alternative forestry policies on household income and food security is a community welfare maximization model. A few studies have attempted to use income maximization to study livestock-based households in Nepal; however, those studies were based on the current policy of reducing use of forests and the subsequent availability of forage resources (Das and Shivakoti, 2006; Hjortso et al., 2006; Thapa and Poudel, 2000). In addition, these studies did not analyze community forests as a common property resource. The purpose of this study is to overcome these gaps by developing a model of community welfare maximization that incorporates common property resource allocation decisions and different policy constraints on forest use and household livestock holdings.

The organization of the paper is as follows. A community economic model that integrates agriculture, forestry and household economic heterogeneity factors is used to analyze policy for managing public forest. Such models are rare in the research literature. A subsequent section describes the analytical model. The study used both survey and secondary sources of data. Data and collection methods are explained before the results section. This study developed and used a problem-specific model to evaluate current and alternative policies. This study examined the impact of current forest policy on household livestock holdings and evaluated alternative policies to enhance food security and livelihoods. The results are presented in three parts: model 
validation, effects of forest policies and alternative policies. Some of the results require discussion before drawing conclusions and policy implications.

\section{METHODS}

\section{An Economic Model of Community-Based Management}

In Nepal typical rural households depend on the resources and opportunities available from their own farms, markets (for buying or selling farm inputs, outputs and labor force) and common property resources (Amacher et al., 1993; Mahat et al., 1987; Adhikari et al., 2004). Households make production and consumption decisions based on the opportunity costs of labor and land resources. Public forest resources complement private resources or substitute for goods produced on private land, while goods in short supply can be purchased from markets. The extent of access to public forest resources is dependent on government policies. The economy of a rural community is composed of an aggregation of member households and common resources. In this context, the community forestry management issue is essentially a resource allocation problem, and different policy scenarios can be analyzed using a linear programming model. The focus of this paper is on the effects of policies rather than the programming model, and therefore, only the objective function and constraints are outlined here. Details regarding the household and community forest models can be found in Appendix 2.

In the model the community is structured as $Z$ different income or 'well-being' groups with $N$ households in each group. In subsistence farming communities land is the most important means of income, and self-sufficiency is an important determinant of household well-being. For modelling simplification, the community households are grouped into three income groups, rich $(\mathrm{R})$, medium $(\mathrm{M})$, and poor $(\mathrm{P})$, based on sufficiency of household income from private 
landholdings to meet basic needs ${ }^{5}$. In this study, poor households are defined as having insufficient private land to meet basic needs, medium households as having sufficient land to meet basic needs, and rich households as having a surplus of land to meet basic needs. The relationship between the private landholdings of rich $(a p R)$, medium $(a p M)$ and poor $(a p P)$ households is:

$$
a^{p P} \leq a^{p M} \leq a^{p R}
$$

For modelling purposes, each income group is assumed to have the same landholding. The community forest is treated as another income group. It can use its resources (the community forest) to produce goods for sale (to community members or externally), or it can lease land to individuals to make their own production decisions over a particular area. Its labor endowment is the sum of the compulsory labor contribution from individual community households. With this structure, total community income $(Y)$ is the sum of household incomes $(y z n)$ and the community forest income $(y c)$.

$$
Y=\left[\sum_{z=1}^{Z} \sum_{n=1}^{N} y_{z n}+y_{c}\right]
$$

The community objective is the maximization of community income subject to constraints on area, labor availability, employment opportunities, the need to meet basic food, heating and housing requirements, a restriction against making individual households worse off to maximize community income and government policies on community forest use. The objective function can be written as,

\footnotetext{
${ }^{5}$ Key informants from the survey communities were asked to categorize households on a poverty scale. They used two main criteria: production of food from private land and annual household cash income Members of most households engaged in lowpaid off-farm work within the country and overseas. Key informants said that the savings generated from off-farm work were notably less than the savings generated from farmwork at home. In the survey, community household incomes were strongly correlated with landholding size. Therefore, we classified the households based on food sufficiency from their own land. However, off-farm income was included in the model when calculating total household income. Other studies have also followed the criteria of landholding size to classify households (Gilbert and Banik, 2010).
} 


$$
\operatorname{Max} Y=\left\lfloor\sum_{j}^{J} \sum_{z}^{Z} \sum_{n}^{N} C_{a j} X_{z n j}+\sum_{j}^{J} \sum_{z}^{Z} \sum_{n}^{N} G_{z n i}\left(C_{c j} X_{j}\right)\right\rfloor
$$

The term $\mathrm{Xj}$ is a vector of decision variables, $C a j$ is a coefficient matrix of decision variables for private endowments and $C c j$ is a coefficient matrix of decision variables for community forest endowments. The term $G$ is the forest policy determined weight of community resources contributing to the production function of household $n$ of income group $z$. This shows that the contribution of community forest to community income differs with government policy. The objective function is subject to the following constraints. The total amount of private land type $k$ used in production system $t$ by $n$ households in $z$ income groups cannot exceed the total amount of private land available (ap). This condition permits share cropping or rental arrangements. Similarly, the total amount of community land used cannot exceed the total amount of community land type available in the $(a c)$.

$$
\begin{aligned}
& \sum_{z=1}^{Z} \sum_{n=1}^{N} \sum_{k=1}^{K} \sum_{t=1}^{T} a_{t k z n}^{p} \leq a^{p} \\
& \sum_{z=1}^{Z} \sum_{n=1}^{N} \sum_{k=1}^{K} \sum_{t=1}^{T} a_{t k z n}^{c} \leq a^{c}
\end{aligned}
$$

Government policy constraints are of two types. One type of policy restricts the area of a particular land type $k$ that can be used $\left(G^{l} k\right)$, and the other restricts the amount of harvest of an output $\left(G^{2} i\right)$. In either case, $G$ is a proportion that takes a value between 0 and 1 .

$$
0 \leq G_{k}^{1}, G_{i}^{2} \leq 1
$$

Labor allocated by any household to their own farm $(L f)$, leisure days $(L O)$, community forest activities $(L c)$, or outside employment $(L m)$ cannot exceed total labor available for that 
household $(L)$ plus hired labor $(L h)$. Employment opportunities are assumed to be limited to what is available in the community from farmers employing labor, so that total off-farm employment (Lmzn) cannot exceed local employment opportunities (Lhzn).

$$
\begin{aligned}
& L_{h}+L=L_{f}+L_{m}+L_{c}+L_{o} \\
& \sum_{z=1}^{Z} \sum_{n=1}^{N}\left(L_{m z n}\right) \leq \sum_{z=1}^{Z} \sum_{n=1}^{N}\left(L_{h z n}\right)
\end{aligned}
$$

A household needs minimum amounts of particular outputs (di) to meet basic needs for food, heating (firewood) and housing (timber). There is also a restriction against making individual households worse off in terms of final income relative to initial income $(y 0 \mathrm{zn})$.

$$
\begin{aligned}
& q_{i} \geq d_{i} \\
& y_{z n} \geq y^{0}{ }_{z n}
\end{aligned}
$$

The general model in Eq. (3) was used to model the effects of different government policy options. Government policy is reflected by changes in the value of particular variables or constraints in the model. The constraints for each policy/management scenario are described below.

\section{A. Scenario A-Current Policy}

Current government community forest policy is used as the base case. The community forest is modelled as a separate production household in the community. In this case, community forest lands are allocated entirely to timber production $\left(G^{1} k=1.0\right.$ for timber and $G^{1} k=0.0$ for all other land uses). The timber harvesting is constrained to an annual harvest of only $30 \%$ of MAI 
for hardwoods and mixed deciduous forests $\left(G^{2} i=0.3\right)$, and 50 percent of MAI for pine forests $\left(G^{2} i=0.5\right)$. Byproducts, including firewood produced from offcuts or residuals, and fodder harvested from understory species are produced for sale. The forest products are available at subsidised prices for members of the group and full price for others. The income of the community forest is modelled as a separate household as is current practice.

\section{B. Scenario B-Unconstrained Community Use}

The community forest is modelled as a separate production household in the community similar to the base case, but with no policy constraints on land allocation for any product or the level of harvest $\left(G^{1} k=1.0\right.$ and $\left.G^{2} i=1.0\right)$. The land allocation for production of firewood, tree fodder or timber and their harvest is based on maximizing income through sales of outputs. As is common practice, community forest members can purchase community forest output at subsidized prices fixed to meet household needs, and surplus products are sold outside the community at market prices.

\section{Scenario C-Unconstrained Lease}

Similar to the Unconstrained Community case, there are no constraints on land use of the community forest for firewood, tree fodder or timber or the level of harvest. However, in this scenario the community forest can be leased to individual households under monitoring and regulation of the community forest user group. This scenario allows households with surplus labor to use community forests as if the land was under private management, effectively increasing the land available to a household. Surplus labor is calculated in terms of households using labor to work on their own private land resources first. The community earns a rental on the area leased to households, and earns income from products from the land remaining in community management. This model is different from the current leasehold forestry policy model found in Nepal. 
Although the alternative policies in $\mathrm{B}$ and $\mathrm{C}$ are notionally unconstrained, the objective is to maintain environmental benefits. Therefore, cereal production is constrained to private land, and the only unconstrained activities allowed on community forests are some combination of fodder, firewood and timber production based on agroforestry land use practices. Nepal has many species of high value fodder trees and sophisticated agroforestry technologies (Thorne et al., 1999; Ives and Messerli, 1989; Mahat et al., 1987). There are a number of agroforestry systems that include livestock, but do not involve grazing. In some agroforestry models fodder trees are mixed with understory pasture grass species, and the cut and carry method is used for fodder supplies (Thorne et al., 1999; Paudel and Tiwari, 1992). Studies have also shown that less intensive livestock grazing has little effect on soil erosion in the mountains (Gilmour et al., 1986). An additional benefit of the agroforestry system is that farmers can use the egesta of livestock mixed with soil to increase soil fertility instead of using chemical fertilizers (Pilbeam et al., 2000). Before applying dung to the soil, some households also use it to produce bio-gas for household energy purposes (Hjortso et al., 2006).

While one of the potential benefits of agroforestry is land stabilization and erosion control, this is not considered to be a major item in this paper. A number of studies have pointed out that natural disasters associated with rainfall, soil erosion and flooding are generally not associated with traditional land use practices and are the outcome of natural processes (geophysical movements and intense rains) that are beyond human control (Wobus et al., 2003; Gerrard and Gardner, 2002; Merz et al., 2006; Ives and Messerli, 1989). The main environmental benefits of the agroforestry land use model are a contribution to biodiversity conservation, carbon sequestration and soil quality (Narain et al., 1997; Montagnini and Nair, 2004; McNeely and Schroth, 2006). Therefore, local environmental services can be greater in agroforestry systems than the current forestry production model (few dominant species and a log production focus). It 
is assumed that forest user groups monitor mismanagement of forest resources in all policy scenarios. As such, the alternatives represent an unconstrained agroforestry alternative that maintains or enhances environmental benefits from forestry.

\section{Data}

This study uses information from household surveys, community forest user group (CFUG) surveys and secondary sources. The primary data for households was collected from six CFUGs in the Dolakha, Kavre and Nuwakot districts of the mid-hill region of Nepal. The first two districts are called 'pioneer' districts for community forest programs in Nepal and are the most accessible districts for monitoring by donors and government agencies. The last district has a low intensity of external support similar to many other districts in the country. The particular CFUGs in each district were selected on the basis of representative forest condition, type of forage-gathering practices, age of the CFUG, forest size and level of access to district forest office services.

For the household survey households were randomly selected from household income group lists in each CFUG. Income grouping is a common practice for evaluating community forestry in Nepal. The grouping involves community people listing households who were considered to be poor, average (medium) and high (rich) income in their communities. A range of criteria are used for classifying income groups, however, the most common criterion is the level of food sufficiency for a household (consumption versus production of food). A total of 259 farming households were surveyed. The household survey was an interview with the female head of household. The female head of household was selected because male heads had a high frequency of seasonal migration out of the community for work, and generally provide less information about farm and forest resource conditions. The enumerators were trained in household survey techniques and had specific training for this survey. 
The household survey consisted of a structured questionnaire that had been pre-tested.

Respondents were asked a range of questions, including their holding of all types of private lands (including sharecropping or leased land), their level of food sufficiency, family size, household labor, livestock holdings, and firewood and timber collection from community forests. Table 1 summarizes private landholdings, community forestland areas and the household labor force. The average private household landholdings found in this survey were higher than those found in Adhikari et al. (2004) who reported average landholdings of 0.15 ha, 0.51 ha and 1.28 ha for poor, medium and rich households respectively. However, the average landholding size is similar to the Agricultural Sample Survey (2003), which reported 0.53 ha, 0.55 ha and 0.68 ha for Nuwakot, Kavre and Dolkha districts respectively (CBS, 2003). Labor force and household size are similar to national standards (NPC, 2003). The sample is thus representative of CFUGs generally in Nepal.

Table 1 near here

The respondents were also asked to report the number of livestock they were holding at the time of the survey and to recall the number of livestock they held before commencement of the community forestry program in their community. Households formed after the commencement of the community forestry program reported only the existing number of livestock. Since households keep different types of livestock that have different total digestible nutrient (TDN) requirements, feed requirements were estimated using a standardized livestock unit. One mature female buffalo, one cow, and one goat are 1.0, 0.7, and 0.2 livestock units respectively (Master Plan, 1988). Two young (calf or kid) are calculated as an adult for each breed to standardize the feed estimation. Data common to all households, such as yields, prices or labor productivity, were collected from local market surveys, key informants, and secondary sources, including FAO (2004, 2003), DOF (2000), Master Plan (1988), Kayastha et al. (2001), MacEvilly (2003), 
Paudel (1992), and Paudel and Tiwari (1992). The full list of references for secondary data sources can be provided upon request. For community forests, the study estimated fodder production in an agroforestry system that consists of fodder trees as the principal crop and grasses between the trees as a mixed crop. Fodder trees are predominantly used for fodder production and for many years. Therefore, the timber potential for production from fodder trees is not included in income maximization. However, firewood production available from the annual lopping for fodder is included. The residual from timber harvest is used as firewood. The outputs of the trees grown on private lands are added to the model as an intercrop component of the farming system. Fodder is an input for livestock production and also an intermediate product from fodder trees, grain by-products, biomass grown on terrace risers or bonds, and inter-tree grasses. Livestock produced manure can be substituted for fertilizer costs in crop production. Surplus grain is used as supplementary concentrated animal feed. Both manure and surplus grain are converted into cash values and included in the model.

The first part of the results provide an estimation of the changes in livestock numbers following commencement of the forestry program based on information from the survey. The results of the linear programming model start with model validation, which shows how accurate the model is at predicting the actual allocation of household and community resources. This is followed by results of livestock numbers and changes in household income levels under different policy scenarios.

\section{RESULT}

\section{Effects of Current Community Forestry Policy on Livestock}

This section presents the results of real changes of household livestock holdings with commencement of the community forestry policy. The respondents were asked to estimate their 
livestock holdings before and after the formation of the CFUG. Figure 1 shows that average livestock holdings were reduced by about 30 percent after the CFUG was formed. The forest policy contributed to reductions in household livestock holdings by $34 \%$ for goats, $30 \%$ for cattle and $27 \%$ for buffalo. The largest reduction was for high income households followed by poor households, for all types of livestock. The reductions for the high income household group were 41,40 , and $32 \%$ for goat, buffalo, and cow, respectively. The reductions for the poor household income group were 36,32 , and $31 \%$ for goat, buffalo, and cow, respectively. However, the percent impact on household income and food security could be higher for the poor household group than the rich household group. Interestingly, the number of buffalo increased in the medium household group. There could be many reasons for the variation in reduction of the number of livestock holdings between household groups. Due to greater on-farm production of livestock feed, the high income household group had the greatest number of animals before commencing the forestry protection program (Adhikari et al., 2007; Mahat et al., 1987). During critical seasons when the high income household group faced a deficit in farm fodder, this household group had used forest fodder and pasture. The poor households had smaller private landholdings and a greater reliance on community forest lands across all seasons. They usually keep goats and cows (Graner, 1997). Those grazing and fodder supplies were not available when grazing was restricted and grass was suppressed by forest after commencing community forest protection (Adhikari et al., 2007; Dhakal et al., 2005). As a result, the rich and poor household groups were affected the most.

Interestingly, the level of reduction in the user groups is related to forest characteristics which vary with conservation practices. Forest policy seems to be an obvious factor causing the reduction; however, there could be other contributing factors such as rural labor force dynamics. In the study communities, the displacement of people associated with armed conflict was not notable at the survey time. Overseas migrations were also few. However, many young people 
migrated to urban areas seasonally. Here we also found variations in reductions between livestock types. Households generally feed goats and cows by grazing on forest fodder, and those animals have been affected the most by changes in community forest management. National livestock statistics show that the reduction in the cattle population is accelerating (CBS, 2003). Buffaloes generally are fed on farm-produced feed and cereals which could be the reason for this type to be least affected. The increase in buffalo numbers for the medium household group was most likely associated with increased access to roads and markets for milk and feed cereal in some study groups. The poor household group could not afford the market feed.

With an average decrease in livestock numbers of about $30 \%$, there would be a 20 to $25 \%$ reduction in farm manure supplies after handing over the forests to the communities. In some groups the livestock numbers were reduced due to the forestry program in two phases: first, through government managed plantation and protection, and then, through strict protection after handing over the forest to a user group. This study examined the household livestock holding reduction after the forest was handed over to local communities. The reduction of livestock had occurred as forest plantation and protection started (Fox, 1993). The livestock holding status before plantation could not be examined in this study. Therefore, the impact of community forestry is much higher than recorded here. The total impact is likely to be the highest for poor households, which are least able to purchase market-supplied fertilizer and food. In terms of welfare, the impact could be enormously higher for households at the margin of food security and for poor ones who already had insufficient resources for bare survival. The findings presented here regarding decreasing household livestock holdings with the commencement of forest conservation policies are similar to other studies (Adkikari et al., 2007; Bhatta, 2002; Fox, 1993). Similar results are reported in other forest-based livestock farming countries like India and China (Cao et al., 2009; Hazari and Kumar, 2003). These results (Figure 1) confirm the common perception that community forestry has had a negative impact on livestock holdings 
and household incomes and set the stage for a study of alternative policies that can increase livestock holdings and incomes.

Figure 1 is near here

\section{Model Validation}

The model developed to analyze the impacts of community forestry on household and community income was validated using mean absolute relative error measures (Buongiorno et al., 2003). The error is the percentage difference between predicted and actual data.

$$
E=\frac{1}{n} \sum\left(\frac{P_{t}-A_{t}}{A_{t}}\right)
$$

where $E$ is the mean absolute error of $n$ number of observations, $P t$ is the predicted quantity of product $t$, and $A t$ is the actual quantity of product $t$. Table 2 shows the actual data, model predictions, and $\mathrm{E}$ for livestock units in each $\mathrm{CFUG}$.

Table 2 is about here

The results of the actual average livestock holdings are consistent with Adhikari et al. (2004) who reported 2.02, 2.85, and 4.3 average livestock units for poor, medium, and rich household income groups, respectively. A negative value for $\mathrm{E}$ in Table 4 means an overestimation, and a positive value means an underestimation. The average errors of actual and predicted livestock units are less than 10 percent within CFUGs and 34\% within household income groups. The distribution of errors of estimated livestock holdings for poor and high income households do not appear to be random, which indicates that there could be some problem in the model. Errors in the model results could arise from a number of factors. These include incomplete data which 
do not adequately capture what is happening in communities, such as inter-household fodder exchange, assumptions about resource management efficiency and livestock production in the model, or resource use decisions that are not based on income maximization as assumed in the model. The highest errors are encountered in the high-income group of the Khorthali user group where many household members were involved in non-farm activities.

In terms of inter-household fodder exchange, there is only a small difference between total actual and predicted livestock units within a CFUG, supporting the logic of inter-household exchanges. A study by Das and Shivakoti (2006) also showed that households keep higher livestock units than estimated from feed resources. In situations of low feed availability, poor households are more likely to feed livestock less fodder and keep animals in poorer health conditions than other households. Moreover, the overestimation for poor households could also be associated with the feed requirement parameters. Due to the lack of local research on livestock TDN requirements in Nepal, this study followed Indian livestock unit standards (Das and Shivakoti, 2006). The Nepalese livestock sizes are relatively smaller than the Indian ones, and this could also be a possible explanation for the difference in model results.

The model presented in this paper makes a simplifying assumption that limits employment opportunities to what is available in the community. However, in developing countries a high income household can invest more in human resource development and business than a poor one, and then become involved in high-income off-farm employment (Ellis and Freeman, 2004). As such, another reason for the underestimation of high income household livestock units could be labor availability for keeping livestock. In cases where there is a family labor shortage it could be more profitable for a rich household to sell fodder to other households than to hire labor. This selling of fodder may lead to lower livestock holdings than the model prediction. The 
validation result indicated that the findings need to be interpreted while accounting for these possible errors in the model.

The validity of the model to predict household food production was tested by comparing food production to the level of surplus or deficit based on the household food sufficiency category. Table 3 shows average household values for food production and a surplus or deficit for the household consumption requirement. Production used for seed is also modeled as consumption because most of the farmers use seeds from their own farm. The food production level of the poor household category in all user groups was lower than needed for household consumption. The production levels of medium households are barely over the consumption requirement. The production levels of rich households are remarkably higher than needed for household consumption. The model predicted these results reasonably well within a small margin of error for most of the groups. One of the prediction errors is surplus production for medium household groups. The surplus was small and probably reflects a good harvest year and some error of estimation. Another notable error is a greater surplus of food production for medium income households than rich households in the Chapanigadi forest user group. The prediction error was due to the fact that the rich household group has an extremely large family size. The result of the validity test indicated that the model predicts reasonably well except for extreme cases.

Table 3 is about here

As a result of these validity tests, it is concluded that the model provides a reasonable characterization of the production and consumption system of a CFUG in Nepal. As such, the model will be useful in analyzing the effects of alternative policies affecting forest use and management. 


\section{Alternative Forest Policies and Livestock Holdings}

Table 4 shows the estimated per household livestock holding units for three household income groups under the different forest policy scenarios defined earlier (Scenarios A, B and C). The results show that household livestock unit holdings increase for all household income groups when forest policy constraints are relaxed (Scenarios B and C). Scenario C, which is the unconstrained lease, results in the largest increase in livestock holdings. The largest increase in livestock holdings is for poor households, increasing from an average of 2.1 livestock units in the Base Case (Scenario A) to 4.4 livestock units in the unconstrained community use case (Scenario B) and 4.5 livestock units in the community lease case (Scenario C). The impact of the policy changes on livestock holdings varies between CFUGs. For example, in the Siddeswori CFUG, there is no change for rich households, while in the Banshkharka CFUG, there is a big increase in the livestock holdings of all households. Accounting for all households, the smallest change was in the Suryamati CFUG.

Table 4 is near here

The results showed that the increases in livestock holding and household incomes are distinctly higher for poor households. The private landholdings of these households were insufficient to employ family labor and produce enough income for basic living. The underemployed labor utilized the community resources, and increased both livestock holdings and household income. Livestock production also increased farm manure production and contributes to food production. On the other hand, the labor from high income households was already absorbed in private land so that this household group could not reap much benefit from the community forestry policy changes. 
The results also showed that variations in the increase of livestock holdings and household incomes among forest user groups were associated with many factors such as forest species type, family labor force, private land and forest sizes. For example, the impact of policy constraints was high for hardwood forest. As a result, the lower number of livestock units reported in the base case of Bashkhaka is associated with more area of broad leaf forest.

The relaxation of policy constraints increased household livestock number and income for the highest in this group. The livestock increases are relatively higher in the unconstrained lease scenario than the unconstrained community scenario. The demand for labor increased in the community scenario due to the many transactions and coordination needed in the communal production system. The lease scenario also allowed more flexibility for private land allocation due to increased supplies of community forest resources. The household income increase of the medium income household group was higher in the Banshkharka-like groups where private landholdings are smaller and per household community forest sizes are relatively larger. Livestock holding has a direct effect on household income levels.

\section{Alternative Polices and Household Income}

Table 5 shows per household incomes under the base case scenario. Poor households, except one group, have insufficient income to meet basic survival. The basic income officially defined by the National Planning Commission for a five-member family is NRs 33,626 for 2003 (NPC, 2003). This income level is based on the requirement for minimum calories and other basic nonfood items. Therefore, there is a great challenge to increase their income to meet their needs.

Table 5 is near here 
Table 6 shows the percentage change in average household income relative to the base case under alternative policies. Similar to livestock changes, incomes increase for most income groups in each CFUG. Poor households have the greatest increase in income, rising between 16 and $72 \%$ (average of $46 \%$ ) under the unconstrained community use policy, and between 44 and $125 \%$ (average of $81 \%$ ) under the unconstrained lease policy. The average income increase for medium income households is $17 \%$ under the unconstrained community use policy, and $27 \%$ under the unconstrained lease policy. For high-income households, incomes were only marginally increased, and for two-thirds of the CFUGs there was effectively no change.

Table 6 is near here

The role of the policy factor was remarkable on livestock holdings and incomes. Under the base case, forestland use was constrained to timber production and with limited harvesting at policy dictated levels (30\% mean annual increment for hardwood species and 60\% for softwood species). That resulted in lower numbers of livestock holdings and lower levels of incomes. Under the unconstrained community and unconstrained lease scenarios the land use policy was unconstrained for fodder tree-based agroforestry systems. The results from the agriculture and forestry integrated model, developed using the income maximization principle, showed that fodder production for livestock farming was the most profitable community forestland use. The agroforestry system increased forage availability to feed livestock which contributed to household income. Under the condition with relaxed policy constraints the increases in fodder production also increased firewood supplies, which reduced land dedicated to firewood production increasing land dedicated to fodder production. The income in the community account decreased in the base case in all CFUGs except Banshkharka. This was due to the fact that alternative policy scenarios allow communities to produce non-timber products, which generate lower income in the community account but generate greater incomes for households. 
Current policy limits production to timber products, which fetch higher prices and result in more income in the community account. However, the overall effect was an increase in total community income with the alternative policies.

\section{CONCLUSIONS AND POLICY IMPLICATIONS}

One of the objectives of this study was to investigate the impact of environmental conservation policies on household livestock holdings. The results of a survey of a number of community forest user groups in Nepal showed that livestock holdings have decreased since the introduction of community forestry. The reason for the reduction in livestock numbers is the focus of current forest policy on forest conservation leading to a reduction in forest grazing and forest fodder supplies. This result implies that new stronger environmental conservation policies may lead to worse food security in Nepal. The REDD project has a clearly stated aim of displacing animal grazing and fodder collection in community forest areas to increase carbon sequestration and storage (World Bank, 2008a; 2008b). The implication of those policies would be reduced livestock numbers as the policies restrict livestock grazing and increase tree canopies suppressing understory forage available for livestock. If the Nepalese government implements the protected area expansion policy, as declared at the Copenhagen Submit of 2009, farmers' access to alpine pastureland (accounting for $10 \%$ of the national area) will almost cease. This, in turn, has further implications for future food security in remote and institutionally disadvantaged localities because cattle provide income for livelihoods, farm power for ploughing and manure for fertilizer.

Environmental policies have affected Nepal's livestock supply countries (India and China). The public lands traditionally used for livestock grazing are also getting forested at high rates (FAO, 
2005). In many Indian rural communities the livestock populations are already affected by forest conservation policies (Hazari and Kumar, 2003; Prasad et al., 2003) as is the situation in China (Cao et al., 2009). In addition, the demand for livestock is increasing in these countries. All the above factors are likely to contribute to higher future prices for livestock products and to further reduce consumption of animal products, particularly for poor households in Nepal. Therefore, the government and international agencies need to implement alternative forest policies that provide livelihoods for poor people and maintain environmental quality.

Another objective of this paper was to investigate whether it is possible to improve food security and increase incomes for poor people through alternative policies in community-based resource management, while maintaining environmental outcomes. The study did this by investigating the impact of current forest policy on livestock holdings in different household income groups in CFUGs in Nepal using a linear-programming approach. Two alternative management policies were examined, one representing an agroforestry model for community forests while maintaining community (common) production, and the other representing a lease model where community forest land is leased to individual households to manage like private land under agroforestry systems. The results of the analysis of the impact of alternative policies shows that livestock numbers and community income can be increased when the current forest policy is changed from a timber orientation to an agroforestry land use system. Both policies increase household livestock holdings and income, primarily for low and medium income households, while still maintaining the required environmental outcomes. This in turn provides greater food security. The unconstrained lease policy provides the greatest increase in income. The results show that both government policies and global environment conservation policies can become obstacles to increasing incomes and providing food sufficiency for rural households. 
This study did not evaluate the impact of payment for ecosystem services of local forests on incomes and food security. That is a subject for future study. Future studies involving community management of resources in a developing country context should focus on evaluating environmental services outcomes under alternative agroforestry policies. The use of sustainable agroforestry systems may give policy makers a greater range of alternatives for meeting both economic development and environmental outcomes. As this paper also shows, the impacts of agroforestry policies are potentially greatest for the most vulnerable, who have a greater reliance on forest resources, and are thus potentially an important tool in combating rural poverty. 


\section{REFERENCES}

Adhikari, B., F. Williams, \& J. Lovett. 2007. Local benefits from community forests in the middle hills of Nepal. Forest Policy and Economics 9 (5): 464-478.

Adhikari, B., S. Di Falco1, \& J. Lovett. 2004. Household characteristics and forest dependency: evidence from common property forest management in Nepal. Ecological Economics. 48(2): $245-257$.

Amacher, G., W. Hyde \& B. Joshee. 1993. Joint production and consumption in traditional households: Fuelwood and crop residues in two districts in Nepal. Journal of Development Studies 30 (1): 206-225.

Bardhan, P. \& C. Urdy. 1999. Development Microeconomics. Oxford University Press, New York.

Bhatta, B. 2002. Access and Equity Issues in Mountain Implications of Community Forestry Program. Policy Analysis in Community Forestry Program. A Compendium of Research Papers. Winrock International-Nepal Policy Analysis in Agriculture related Resource Management (PAARRM) program. Kathmandu.

Buongiorno, J., S. Zhu D. Zhang J. Turner, \& D. Tomberlin. 2003. The Global Forest Products Model: Structure, Estimation, and Applications. San Diego: Academic Press. 
Cao, S. X. Wang, Y. Song, L. Chen, \& Q. Feng. 2009. Impacts of the natural forest conservation program on the livelihoods of residents of northwestern China: Perceptions of residents affected by the program. Ecological Economics 69 (7): 1454-1462.

CBS. [Central Bureau of Statistics]. 2003. National Sample Census of Agriculture Nepal. 2001/02. Highlights. Kathmandu: Central Bureau of Statistics.

CBS [Central Bureau of Statistics]. 2002. Statistical Yearbook Nepal. Kathmandu: Central Bureau of Statistics.

CBS. 2008. Environmental Statistics of Nepal 2008. Kathmandu, Nepal: Central Bureau of Statistics.

Das, R. \& G. Shivakoti. 2006. Livestock carrying capacity evaluation in an integrated farming system: A case study from the mid-hills of Nepal. International Journal of Sustainable Development and World Ecology 13 (3): 153-163.

Dhakal, B. \& B. Bhatta. 2009. An institutional model to explain utilization problems of community forest products. International Journal of Social Forestry 2(2): 122-135.

Dhakal, B., H. Bigsby, \& R. Cullen. 2007. The link between community forestry policies, and poverty and unemployment in rural Nepal. Mountain Research and Development 27 (1): 32-39.

Dhakal, B., H. Bigsby, \& R. Cullen. 2005. Impacts of community forestry development on livestock-based livelihood in Nepal. Journal of Forest and Livelihood 4(2): 43-49. 
DOF, 2002. Community Forest Resource Inventory Guidelines, 2061, Community Forest

Division, Department of Forest, Kathmandu, Nepal. Department of National Park and Wildlife Conservation (DNPWC), 2010. Protected area. http://www.dnpwc.gov.np/protected-areas.asp. Accessed on 25 June 2010.

Edmonds, E. 2003. Development assistance and the construction of government-initiated community institutions. Economic Development and Cultural Change 51(4): 897-930.

Ellis, F. \& H. Freeman. 2004. Rural livelihoods and poverty reduction strategies in four African countries. Journal of Development Studies 40(4): 1-30.

Fafchamps, M. \& F. Shilpi. 2003. The spatial division of labour in Nepal. Journal of Development Studies 39(6): 23-66.

FAO. 2008. Crop Prospects and Food Situation. Retrieved from http://www.fao.org/ docrep/010/ai465e/ai465e00.htm

FAO. 2004. Food and Agricultural Indicators. Retrieved from http://www.fao.org/es/ess/compendium_2004/pdf/ESS_NEP.pdf

FAO. 2003. FAO Nutrient Response Database: FERTIBASE Retrieved from http://www.fao.org/ag/agl/agll/nrdb/country.jsp?lang=en\&what=\&setting=\&COUNTRY_ID=NEPAL\&CROP_GR

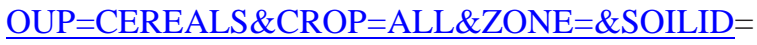


Fox, J. 1993. Forest Resources in a Nepali village in 1980 and 1990: The positive influence of population growth. Mountain Research and Development 13(1): 89-98.

Gautam, B. R. 2009. Question of accountability; A case of diarrhea outbreak of mid and far West. Informal 28 (3): 4-8.

Gautam, A.; E. Webb, \& A. Eiumnoh. 2002. GIS assessment of land use/land cover changes associated with community forestry implementation in the Middle Hills of Nepal. Mountain Research and Development 22(1): 63-69.

Gerrard, J. \& R. Gardner. 2002. Relationship between land-sliding and land use in the Likhu Khola Drainage Basin, Middle Hills, Nepal. Mountain Research and Development, 22(1): 4855.

Gilbert, J. \& N. Banik. 2010. Socioeconomic Impacts of Cross-Border Transport Infrastructure Development in South Asia. ADBI Working Paper 211. Tokyo: Asian Development Bank Institute. Retrieved from http://www.adbi.org/ workingpaper/2010/04/14/3655.socioeconomic.transport.infrastructure/

Ghimire, S. 1992. The Role of Small Ruminants. In Edited by J.B. Abington. Sustainable Livestock Production in the Mountain Agro-Ecosystem of Nepal. Pp. 77-110. Food and Agricultural Organization of the United Nations: Rome.

Gilmour, D., M. Bonell, \& D. Cassells. 1986. The effects of forestation on soil hydraulic properties in the middle hills of Nepal: A preliminary assessment. Mountain Research and Development 7(3): 239-249. 
Graner, E. 1997. The Political Ecology of Community Forestry in Nepal. Verlag fur

Entwickungspolitik. Saarbruken.

Hazari B. R, \& A. Kumar. 2003. Caste, land and livestock holdings in India: An analysis.

International Forestry Review 5(4): 364-369.

Hausler, S. 1993. Community forestry: A critical assessment: The case of Nepal. The Ecologist 23(3): 84-91.

Hjortso, C., S. Straede, \& F. Helles. 2006. Applying multi-criteria decision-making to protected areas and buffer zone management: A case study in the Royal Chitwan National Park, Nepal. Journal of Forest Economics 12(2): 91-108.

Hobley, M. 1996. Participatory Forestry: The Process of Change in India and Nepal. Rural Development Forestry Network, Overseas Development Institute: London.

Ives, J. \& B. Messerli. 1989. The Himalayan Dilemma Reconciling Development and Conservation. The United Nations University and Routledge: London \& New York.

Joshi, B. 1992. The Role of Large Ruminants. In Edited by J.B. Abington. Sustainable Livestock Production in the Mountain Agro-Ecosystem of Nepal. Pp. 47-76. Food and Agricultural Organization of the United Nation: Rome. 
Kayastha, B., S. Pradhan., N. Rasaily, S. Dangal, \& F. Arentz. 2001. Community Forest Product Marketing Options for Timber and Non-timber Forest Products 2001. Discussion Paper. Nepal Australia Community Forestry Management Project. No-Frills Consultants.

Khanal, K.P. 2002. Under utilisation in community forestry: A case study from Lalitpur district. Banko Janakari (Journal of Forestry) 12(2): 26-32.

LRMP. 1986. Land Resource Mapping Project. Soil Report. Government of Nepal/Government of Canada.

Mahat, T., D. Griffin, \& K. Shepherd. 1987. Human impacts on some forests of the Middle Hills of Nepal Part 3. Forests in the subsistence economy of Sindhu Palchok and Kavre Palanchok. Mountain Research and Development 7(1): 53-70.

Master Plan. 1988. The Forestry Sector Master Plan. Ministry of Forest, Nepal: Kathmandu.

MacEvilly, C. 2003. Cereals. In Edited by Benjamin Caballero, Luiz C Trugo and Paul M Finglas. Encyclopedia of Food Science and Nutrition. Second Edition. Amsterdam: Academic Press.

McNeely, J. \& G. Schroth. 2006. Agroforestry and biodiversity conservation - traditional practices, present dynamics, and lessons for the future. Journal of Biodiversity and Conservation 15(2): 549-554. 
Merz, J., P.M. Dangol, M.P. Dhakal, B. S. Dongol, G. Nakarmi, \& R. Weingartner. 2006.

Rainfall-runoff events in a middle mountain catchment of Nepal. Journal of Hydrology 331 (34): $446-458$.

Metz, J. 1994. Forest product use at an upper elevation village in Nepal. Environmental Management 18 (3): 371-390.

MOA. 2004. Livestock Export and Import Statistics Database. Animal Quarantine Section. Ministry of Agriculture, Kathmandu.

Montagnini, F. \& P. Nair. 2004. Carbon sequestration: An underexploited environmental benefit of agroforestry systems. Journal Agroforestry Systems 61-62(1-3): 281-295.

Muller-Böker, U. \& M. Kolmar. 2000. Livelihood strategies and local perceptions of a new nature conservation project in Nepal: The Kanchenjunga Conservation Area Project. Mountain Research and Development 20(4): 324-331.

Narain, P., R. Singh N. Sindhwal, \& P. Joshie. 1997. Agroforestry for soil and water conservation in the western Himalayan Valley Region of India: Runoff, soil and nutrient losses. Journal Agroforestry Systems 39(2): 175-189.

Nepal Monitor. 2009. A call from the top of the world: Text of Mt. Everest Declaration 2009. The National Online Journal on Media \& Publication. http://www. nepalmonitor.com/2009/12/a_call_from_the_top.html. Downloaded on $24^{\text {th }}$ June 2010. 
NPC. 2003. The Tenth Plan 2002-2007 (Poverty Reduction Strategy Paper). National Planning

Commission, Kathmandu, Nepal. Accessed in December 2005

http://www.npc.gov.np/tenthplan/.

NRB (Nepal Rastra Bank). Asian Development Bank and Nepal. Nepal Rastra Bank Research Department, Kathmandu Nepal. Accessed May 2008 from http://www.nrb.org.np/red/publication/Special_Publications-ADB\%20\&\%20Nepal_(2004).pdf.

Paudel, K. 1992. Implication of Forage and Livestock production on Soil Fertility. In Edited by J.B. Abington. Sustainable Livestock Production in the Mountain Agro-Ecosystem of Nepal. Pp. 155-170. Food and Agricultural Organization of the United Nations: Rome.

Paudel, K. \& B. Tiwari. 1992. Fodder and Forage Production. In Edited by J.B. Abington. Sustainable Livestock Production in the Mountain Agro-Ecosystem of Nepal. Pp. 131-154. Food and Agricultural Organization of the United Nations: Rome.

Pilbeam, C., B. Tripathi D. Sherchan,. P. Gregory, \& J. Gaunt. 2000. Nitrogen balances for households in the mid-hills of Nepal. Agriculture Ecosystems and Environment 79(1): 61-72.

Prasad, V., K. Badarinath, H. Tsuruta, S. Sudo, S. Yonemura, J. Cardina, B. Stinner, R. Moore, D. Stinner, \& C. Hoy. 2003. Implications of land use changes on carbon dynamics and sequestration-Evaluation from forestry datasets India. Environmentalist 23(2): 175-187.

Richards, M., M. Maharjan, \& K. Kanel. 2003. Economics, poverty and transparency: Measuring equity in forest user groups. Journal of Forest and Livelihood 3(1): 91-106. 
Riethmuller, P. 2003. The social impact of livestock: A developing country perspective. Animal Science Journal 74: 245-254.

SDC-Helvetas. 2009. Promoting food self-sufficiency in the mid-hills of Nepal: Fertilisers or farmyard manure? Mountain Forum Bulletin IX (1): 29-35.

Shrestha, U. B., B. B. Shrestha, \& S. Shrestha. 2010. Biodiversity conservation in community forests of Nepal: Rhetoric and reality. International Journal of Biodiversity and Conservation 2 (5): 98-104.

Taylor, E. \& I. Adelman. 2003. Agricultural Household Models: Genesis, evolutions, and extensions. Review of Economics of Household 1 (1/2): 33-58.

Thapa, G \& P S. Poudel. 2000. Evaluation of livestock carrying capacity of land resources in the hills of Nepal based on total digestive nutrient analysis. Journal of Agricultural Ecosystem and Environment 78(4): 223-235.

Thoms, C. A. 2008. Community control of resources and the challenge of improving local livelihoods: A critical examination of community forestry in Nepal. Geoforum 39(3): 14521465

Thorne, P.J., D.B. Subba, D.H. Walker, B. Thapa, C.D. Wood, \& F. L. Sinclair. 1999. The basis of indigenous knowledge of tree fodder quality and its implications for improving the use of tree fodder in developing countries. Animal Feed Science and Technology 81(1-2): 119-131.

UNDP. 2005. Nepal Millennium Goal. Progress Report 2005. Accessed March 2006 http://www.undp.org.np/publications/mdg. 
Wobus, C., K. Hodges, and K. Whipple. 2003. Has focused denudation sustained active thrusting at the Himalayan topographic front? Geology 31(10): 861-864.

World Bank. 2008a. First Countries Named to Benefit from Forest Carbon Partnership Facility. Retrieved from http://web.worldbank.org/WBSITE/EXTERNAL/NEWS/0,,contentMDK:21846447 menuPK:34463 pagePK:34370 piPK:3442 4 theSitePK:4607,00.html.

World Bank. 2008b. Methodology for Estimating Reductions of GHG Emissions from Mosaic Deforestation. Retrieved from http://carbonfinance.org/Routercfm?Page=DocLib\&CatalogID=41513.

World Bank. 2004. Mapping and Analysis of Agricultural Trade Liberalization in South Asia. Retrieved from http://www.unescap.org/tid/projects/agrnego_sama.pdf. 
Table 1 Average Land Areas, Household (HH) Labour Force and Household Size

\begin{tabular}{|c|c|c|c|c|c|c|}
\hline \multirow{2}{*}{$\begin{array}{l}\text { Forest User } \\
\text { Group }\end{array}$} & \multicolumn{3}{|c|}{$\begin{array}{l}\text { Private Landholding Area } \\
\qquad(\mathrm{Ha} / \mathrm{HH})\end{array}$} & \multirow{2}{*}{$\begin{array}{c}\text { Community } \\
\text { Forest Area } \\
(\mathrm{Ha} / \mathrm{HH})\end{array}$} & \multirow{2}{*}{$\begin{array}{l}\text { Labour Force } \\
\text { (Persons/HH) }\end{array}$} & \multirow{2}{*}{$\begin{array}{c}\text { Household } \\
\text { Size } \\
\text { (Persons/HH) }\end{array}$} \\
\hline & $\begin{array}{l}\text { Poor } \\
\text { HH }\end{array}$ & $\begin{array}{c}\text { Medium } \\
\text { HH }\end{array}$ & Rich HH & & & \\
\hline Khorthali & 0.40 & 1.06 & 2.03 & 0.35 & 3.4 & 4.6 \\
\hline Siddeswori & 0.24 & 0.78 & 2.06 & 0.42 & 3.0 & 6.0 \\
\hline Chapanigadi & 0.67 & 1.03 & 2.75 & 0.90 & 3.6 & 6.2 \\
\hline Banshkharka & 0.46 & 0.76 & 1.08 & 0.83 & 3.1 & 4.9 \\
\hline Bidur & 0.29 & 0.88 & 1.18 & 0.62 & 3.3 & 8.6 \\
\hline Surayamati & 0.42 & 0.73 & 0.93 & 0.62 & 2.8 & 5.9 \\
\hline
\end{tabular}


Table 2 Comparison of Actual and Predicted Livestock Holdings (Livestock Units per household)

\begin{tabular}{|c|c|c|c|c|c|c|c|c|c|c|}
\hline \multirow{2}{*}{ User Group } & \multicolumn{3}{|c|}{ Poor Household } & \multicolumn{3}{|c|}{ Medium Household } & \multicolumn{3}{|c|}{ High Household } & \multirow{2}{*}{$\begin{array}{c}\begin{array}{c}\text { Average All } \\
\text { Households }\end{array} \\
\text { E } \\
(\%)\end{array}$} \\
\hline & Actual & Predicted & $(\%)$ & Actual & Predicted & $(\%)$ & Actual & Predicted & $(\%)$ & \\
\hline Khorthali & 2.1 & 1.3 & 38 & 4.2 & 2.4 & 43 & 1.6 & 4.6 & -191 & -5 \\
\hline Siddeswori & 2.7 & 2.1 & 23 & 3.8 & 3.5 & 6 & 3.8 & 5.2 & -38 & -5 \\
\hline Chapanigadi & 2.7 & 2.5 & 8 & 3.7 & 2.5 & 33 & 5.6 & 7.4 & -31 & -2 \\
\hline BanshKharka & 2.1 & 1.3 & 37 & 2.5 & 2.5 & 0 & 2.7 & 3.3 & -23 & 2 \\
\hline Bidur & 2.2 & 1.8 & 18 & 3.1 & 3.7 & -21 & 3.6 & 4.1 & -14 & -8 \\
\hline Suryamati & 3.4 & 3.4 & 0 & 3.5 & 3.6 & -5 & 3.9 & 2.8 & 28 & 9 \\
\hline Average & 2.6 & 2.1 & 17 & 3.2 & 2.9 & 11 & 3.3 & 4.4 & -33 & -3 \\
\hline
\end{tabular}

Note: Negative E means over-prediction, positive E means under-prediction 
Figure 1 Change in Livestock Numbers by Household after Community Forestry Introduction

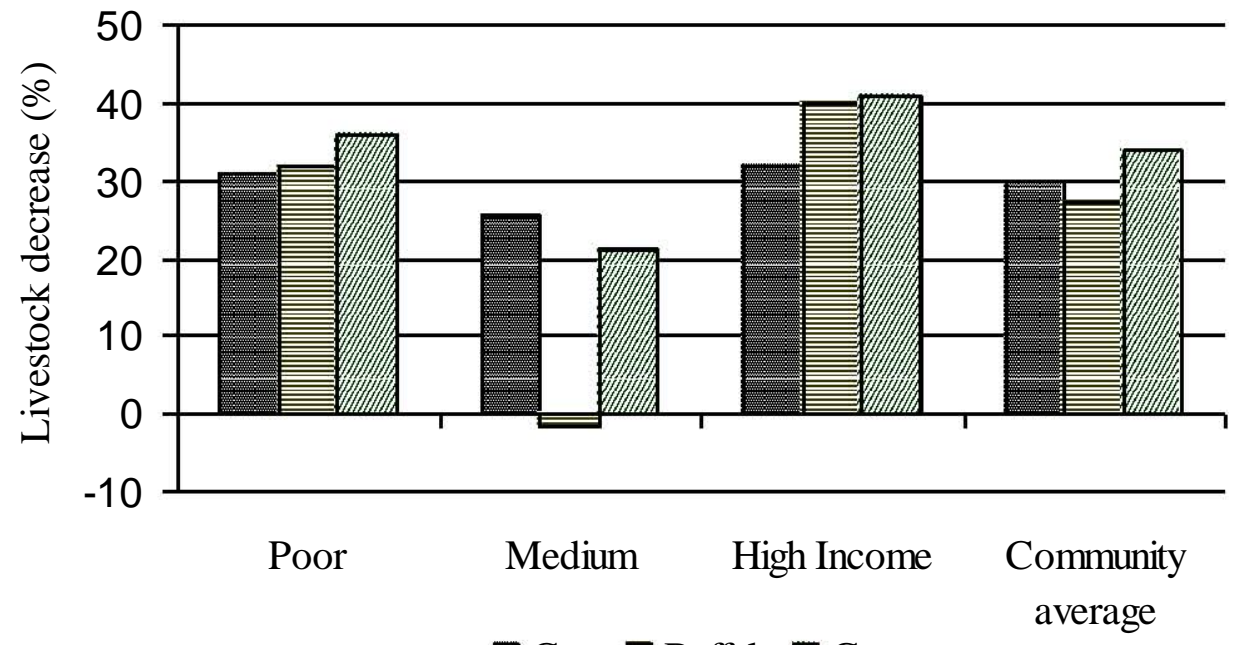

DCow 目 Buffalo Goat 
Table 3 Estimated Average Food Production Surplus or Deficit by Household Types

\begin{tabular}{|c|c|c|c|c|c|c|}
\hline $\begin{array}{l}\text { User } \\
\text { group }\end{array}$ & $\begin{array}{l}\text { House } \\
\text { hold type }\end{array}$ & $\begin{array}{l}\text { Own food } \\
\text { production } \\
\text { (Mega } \\
\text { calories) }\end{array}$ & $\begin{array}{l}\text { Need for } \\
\text { consumption } \\
\& \text { seed(Mega } \\
\text { calories) }\end{array}$ & $\begin{array}{l}\text { Surplus } \\
\text { (deficit) } \\
\text { (Mega } \\
\text { calories) }\end{array}$ & $\begin{array}{l}\text { Per capita } \\
\text { surplus (deficit) } \\
\text { (Mega calories) }\end{array}$ & $\begin{array}{l}\text { Surplus } \\
\text { (deficit) } \\
\text { percent }\end{array}$ \\
\hline \multirow{3}{*}{$\begin{array}{l}\text { Khorthal } \\
\text { i }\end{array}$} & Poor & 2620 & 3128 & (508) & (139) & (27) \\
\hline & Medium & 6948 & 4289 & 2659 & 532 & 20 \\
\hline & Rich & 13593 & 4817 & 8776 & 1563 & 18 \\
\hline \multirow{3}{*}{$\begin{array}{l}\text { Siddesw } \\
\text { ori }\end{array}$} & Poor & 3397 & 4694 & (1296) & $(236)$ & (18) \\
\hline & Medium & 7886 & 4675 & 3211 & 584 & 18 \\
\hline & Rich & 17730 & 5147 & 12584 & 2097 & 17 \\
\hline \multirow{3}{*}{$\begin{array}{l}\text { Chapani } \\
\text { gadi }\end{array}$} & Poor & 4167 & 4325 & (158) & (31) & (20) \\
\hline & Medium & 6638 & 4074 & 2563 & 540 & 21 \\
\hline & Rich & 14553 & 10293 & 4260 & 355 & 8 \\
\hline \multirow{3}{*}{$\begin{array}{l}\text { BanshK } \\
\text { harka }\end{array}$} & Poor & 3629 & 4491 & $(861)$ & $(165)$ & (19) \\
\hline & Medium & 5629 & 4254 & 1375 & 277 & 20 \\
\hline & Rich & 8627 & 3860 & 4767 & 1059 & 22 \\
\hline \multirow[t]{3}{*}{ Bidur } & Poor & 3539 & 6228 & (2689) & $(370)$ & (14) \\
\hline & Medium & 10203 & 8310 & 1893 & 194 & 10 \\
\hline & Rich & 12585 & 9703 & 2882 & 253 & 9 \\
\hline \multirow[t]{3}{*}{$\begin{array}{l}\text { Suryama } \\
\text { ti }\end{array}$} & Poor & 4410 & 4889 & (479) & (84) & (18) \\
\hline & Medium & 7220 & 5337 & 1883 & 303 & 16 \\
\hline & Rich & 8409 & 5147 & 3263 & 544 & 17 \\
\hline
\end{tabular}

Note; This study showed that 44 percent people have food deficit. The family size of the food deficit households is generally larger. 
Table 4 Average Household Livestock Holdings under Different Policy Scenarios (Livestock Units)

\begin{tabular}{|c|c|c|c|c|c|c|c|c|}
\hline $\begin{array}{l}\text { Income } \\
\text { Group }\end{array}$ & $\begin{array}{c}\text { Policy } \\
\text { Scenario }\end{array}$ & $\begin{array}{l}\text { Khor } \\
\text { thali }\end{array}$ & $\begin{array}{l}\text { Sidde } \\
\text { swori }\end{array}$ & $\begin{array}{c}\text { Chapani } \\
\text { gadi }\end{array}$ & $\begin{array}{l}\text { Bansh } \\
\text { Kharka }\end{array}$ & Bidur & $\begin{array}{r}\text { Surya } \\
\text { mati }\end{array}$ & Average \\
\hline \multirow{3}{*}{$\begin{array}{c}\text { Poor } \\
\text { House } \\
\text { holds }\end{array}$} & Base case & 1.3 & 2.1 & 2.5 & 1.3 & 1.8 & 3.4 & 2.1 \\
\hline & $\begin{array}{l}\text { Unconstrained } \\
\text { Community }\end{array}$ & 2.4 & 4.6 & 5.7 & 4.0 & 5.0 & 4.6 & 4.4 \\
\hline & $\begin{array}{l}\text { Unconstrained } \\
\text { Lease }\end{array}$ & 3.0 & 4.6 & 5.8 & 4.0 & 5.1 & 4.7 & 4.5 \\
\hline \multirow{3}{*}{$\begin{array}{c}\text { Medium } \\
\text { House } \\
\text { holds }\end{array}$} & Base case & 2.4 & 3.5 & 2.5 & 2.5 & 3.7 & 3.6 & 3.0 \\
\hline & $\begin{array}{l}\text { Unconstrained } \\
\text { Community }\end{array}$ & 3.3 & 3.6 & 3.4 & 5.0 & 5.0 & 3.8 & 4.0 \\
\hline & $\begin{array}{l}\text { Unconstrained } \\
\text { Lease }\end{array}$ & 3.9 & 3.7 & 3.4 & 5.2 & 5.0 & 3.9 & 4.2 \\
\hline \multirow{3}{*}{$\begin{array}{l}\text { Rich } \\
\text { House } \\
\text { holds }\end{array}$} & Base case & 4.6 & 5.2 & 7.4 & 3.3 & 4.1 & 2.8 & 4.6 \\
\hline & $\begin{array}{l}\text { Unconstrained } \\
\text { Community }\end{array}$ & 5.3 & 5.1 & 7.5 & 5.8 & 4.1 & 2.8 & 5.1 \\
\hline & $\begin{array}{l}\text { Unconstrained } \\
\text { Lease }\end{array}$ & 5.7 & 5.1 & 7.5 & 6.0 & 4.2 & 2.8 & 5.2 \\
\hline
\end{tabular}


Table 5 Base Case Household and Community Incomes (Rs/HH)

\begin{tabular}{|l|r|r|r|r|r|}
\hline CFUG & $\begin{array}{c}\text { Poor } \\
(\text { Rs/HH })\end{array}$ & $\begin{array}{c}\text { Medium } \\
(\mathrm{Rs} / \mathrm{HH})\end{array}$ & $\begin{array}{c}\text { High } \\
(\mathrm{Rs} / \mathrm{HH})\end{array}$ & $\begin{array}{c}\text { Common } \\
(\mathrm{Rs} / \mathrm{HH})\end{array}$ & $\begin{array}{c}\text { Total } \\
\text { Community }\end{array}$ \\
\hline Khorthali & 15541 & 39081 & 76966 & 8292 & 139880 \\
\hline Siddeswori & 29454 & 53886 & 102797 & 10557 & 196693 \\
\hline Chapanigadi & 30745 & 43181 & 118041 & 25904 & 217870 \\
\hline Banshkharka & 20408 & 35169 & 52867 & 7250 & 115693 \\
\hline Bidur & 22379 & 68908 & 83717 & 12384 & 187389 \\
\hline Suryamati & 35701 & 50110 & 54367 & 21143 & 161320 \\
\hline
\end{tabular}


Table 6 Percentage Change in average Household Income, Community Forest Income and Total Community Income from the Base Case under Alternative Policies

\begin{tabular}{|c|c|c|c|c|c|c|}
\hline CFUG & Policy & $\begin{array}{c}\text { Poor } \\
\mathrm{HH}\end{array}$ & $\begin{array}{c}\text { Medium } \\
\mathrm{HH}\end{array}$ & $\begin{array}{c}\text { Rich } \\
\mathrm{HH}\end{array}$ & $\begin{array}{c}\text { Community } \\
\text { forest }\end{array}$ & $\begin{array}{c}\text { Total } \\
\text { Community }\end{array}$ \\
\hline \multirow{2}{*}{ Khorthali } & Community & 49 & 18 & 7 & -41 & 12 \\
\hline & Lease & 64 & 26 & 13 & -66 & 18 \\
\hline \multirow{2}{*}{ Sideswori } & Community & 16 & 2 & 0 & -34 & 1 \\
\hline & Lease & 54 & 8 & 0 & -70 & 7 \\
\hline \multirow{2}{*}{ Chapanigadi } & Community & 49 & 16 & 1 & -51 & 5 \\
\hline & Lease & 88 & 17 & 9 & -73 & 12 \\
\hline \multirow{2}{*}{ Banshkharka } & Community & 72 & 41 & 28 & 97 & 44 \\
\hline & Lease & 110 & 70 & 47 & 29 & 64 \\
\hline \multirow{2}{*}{ Bidur } & Community & 66 & 11 & 0 & -12 & 11 \\
\hline & Lease & 125 & 24 & 5 & -55 & 22 \\
\hline \multirow{2}{*}{ Suryamati } & Community & 26 & 11 & 0 & -49 & 3 \\
\hline & Lease & 44 & 17 & 0 & -83 & 3 \\
\hline
\end{tabular}




\section{Appendixes}

Table A1 Changes in livestock trade (head) between 1987/88 and 2002/3

\begin{tabular}{|c|c|c|c|c|c|}
\hline \multirow[b]{2}{*}{ Breed } & \multirow{2}{*}{$\begin{array}{l}\text { Source } \\
\text { Country }\end{array}$} & & \multicolumn{2}{|c|}{$\begin{array}{l}\text { Livestock Imports in } \\
\text { Fiscal Year }\end{array}$} & \multirow{2}{*}{$\begin{array}{l}\text { Annual } \\
\text { change in } \\
\text { trade }(\%) \\
\text { from } \\
1987 / 88\end{array}$} \\
\hline & & & $1987 / 88$ & $2001 / 2002$ & \\
\hline \multirow{3}{*}{ Buffalo } & \multirow[t]{2}{*}{ India } & Import & 130000 & 215528 & 5 \\
\hline & & Export & 82070 & 10315 & -6 \\
\hline & & $\begin{array}{l}\text { Net } \\
\text { import }\end{array}$ & 47930 & 205213 & 23 \\
\hline \multirow{3}{*}{ Cattle* } & \multirow[t]{2}{*}{ India } & Import & - & 18940 & - \\
\hline & & Export & 73894 & 1538 & -7 \\
\hline & & $\begin{array}{l}\text { Net } \\
\text { import }\end{array}$ & - & 17402 & - \\
\hline \multirow{4}{*}{ Goat } & \multirow[t]{2}{*}{ India } & Import & 130,938 & 393179 & 14 \\
\hline & & Export & 117036 & 36866 & -5 \\
\hline & Tibet & Import & 5084 & $* *$ & - \\
\hline & & $\begin{array}{l}\text { Net } \\
\text { import }\end{array}$ & 21,451 & 356313 & 112 \\
\hline \multirow{4}{*}{ Sheep } & \multirow[t]{2}{*}{ India } & Import & 18691 & 28476 & 4 \\
\hline & & Export & 10260 & 7310 & -2 \\
\hline & Tibet & Import & 22363 & $103887 * *$ & 26 \\
\hline & & $\begin{array}{l}\text { Net } \\
\text { import }\end{array}$ & 30794 & 125053 & 22 \\
\hline
\end{tabular}

Note: $\quad *$ Data for cattle exports to Tibet are not officially recorded and are estimated at about 2000 head. **Data for sheep and goat imports from Tibet in 2001/2 were not separated. Source: MOA 2004, Ghimire 1992 and Joshi 1992 


\section{APPENDIX B}

Household Resource and Production System

Agriculture and forestry production systems can produce more than one product at a time (Amacher et al., 1993; Mahat et al., 1987). Like other linear programming-based studies (e.g., Das and Shivakoti, 2006), it is assumed that the marginal product is constant. Land is defined as $k$ different categories, in this case upland, lowland, sharecropping, grassland, and forest. Land available to a household includes land that is owned by a household and land that is held under sharecropping. Each land category has distinct properties in terms of production systems for different outputs. Output of any good $i$ under production system $t$ on land type $k$ is a function of yield per unit area (Ritk) and the area of land type $k$ allocated to a particular production system by a household (atk). Products may be a single output from a production system or by-products. The outputs range from cereal and livestock to forest products. Total output of any particular good by a household (qi) is then a function of how much land of various types the household allocates to different production systems.

$$
q_{i}=\sum_{k=1}^{K} \sum_{t=1}^{T}\left(R_{i t k} \cdot a_{t k}\right)
$$

The land areas used under different production systems for a particular land type cannot be greater than the endowment of that land type (Eq. A.2). Both output and land use are subject to nonnegativity restrictions $\left(q_{i}\right.$ and $\left.a_{t k} \leq 0\right)$.

$$
\sum_{t=1}^{T} a_{t k} \leq a_{k}
$$

One of the uses of land and labor can be livestock farming. Fodder, grasses and crop by-products can be used as feed for livestock. Because of differences in nutritional values of products, feed production is standardized into total digestible nutrients per unit of output $i(\lambda i)$. Farmers can 
also use purchased feed supplements $(\xi)$. The total digestible nutrients requirement for each livestock type $u(\lambda u)$ is different. Therefore, the number of livestock units of type $u(\theta u)$ that can be farmed is a function of the locally produced feed allocated to that livestock type (qiu) and its nutritional value, purchased supplements and the nutritional requirements of that livestock type,

$$
\theta_{u}=\left[\sum_{i}^{I} q_{i u} \lambda_{i}+\xi\right] / \lambda_{u}
$$

In a subsistence agricultural household, household labor contributes to production from the perspective of entrepreneur, manager and laborer (Taylor and Adelman, 2003; Bardhan and Urdy, 1999). Labor supply can come from the household, or be hired from outside. Household labor requirements for a particular output will be either a function of the area of land type $k$ allocated to a particular production system $t$ by a household (atk) and labor hours required per unit area (ha tk), or a function of output ( $q i)$ and harvest productivity for that good $(h v i)$. Total household labor required on the farm $(L f)$ is then the sum of area-based labor requirements and volume-based labor requirements,

$$
L_{f}=\sum_{k=1}^{K} \sum_{t=1}^{T}\left(h^{a}{ }_{t k} \cdot a_{t k}\right)+\sum_{i=1}^{I}\left(h^{v}{ }_{i} \cdot q_{i}\right)
$$

The amount of hired labor $(L h)$ required is a function of total available family labor days $(L)$, labor required on the farm $(L f)$, leisure days $(L O)$, days spent working off the farm $(L m)$, and days contributed to community forestry $(L c)$.

$$
L_{h}=L-L_{f}-L_{m}-L_{c}-L_{o}
$$

In some cases, purchased inputs may be required by a household for a particular output. These may be a function either of the area under production or the quantity of output. Area-related costs depend on the input cost per unit area of land type $k$ allocated to a particular use $t$ by a household (Stk) and the area allocated to that use (atk). When input costs are related to output then the cost depends on the costs per unit output for that good (Si) and amount of output (qi) in 
land type k. Similar to the labor case the production inputs that are purchased are accounted for as costs. Total purchased input

cost for output $i\left(\_i\right)$ is then,

$$
\Psi_{i}=\sum_{k=1}^{K}\left(q_{i k} \cdot S_{i k}\right)+\sum_{k=1}^{K}\left(a_{i k} \cdot S_{i k}\right)
$$

Net income from producing output $(D)$ is the difference between revenue and costs. All household output is valued at the farm gate price of that output $(P i s)$ irrespective of whether it is consumed by the household or is surplus to household needs and is sold. For simplification, only labor that is hired $(\mathrm{Lh})$ is accounted for as a cash cost. Hired labor is paid a daily wage rate $(w)$. The household also needs to pay rent $(\delta k)$ for sharecropping and leasing community forest of land type $k(a k L)$. The rent could be a positive cashflow for households who lease land to others for sharecropping.

$$
D=\sum_{i=1}^{I}\left(P_{i}^{s} q_{i}-\Psi_{i}\right)-L_{h} w-\sum_{k=1}^{K} a_{k}^{L} \delta_{k}
$$

Net household income $(y)$ includes net income from producing output $(D)$, external income from providing labor $(\mathrm{Lm})$ to the labor market and earning a wage rate $(w)$. It is assumed that a household will either earn outside income (Lm) or employ outside labor (Lh), but will not do both. A household's consumption of goods comes from its own production and from market purchases. When needed, a household can buy products $(q i \mathrm{~m})$ at the market price $(\mathrm{Pi} \mathrm{m})$, where $P i s<P i m$ and the difference between $P i s$ and $P i m$ is market transaction costs and intermediaries' profits. When available, a household may also buy products from the community forest, qi $c$, usually at a special community price $(P i c)$.

$$
y=D+L_{m} w-\sum_{i=1}^{I}\left(P_{i}^{m} q_{i}^{m}\right)-\sum_{i=1}^{I}\left(P_{i}^{c} q_{i}^{c}\right)
$$


Total community income $(Y)$ is the sum of all $N$ household incomes $(y n)$ and community forest income $(y c)$.

$$
Y=\left[\sum_{n=1}^{N} y_{n}+y_{c}\right]_{-}
$$

Policy and Community Forest Management

To a large extent, the community forest can be treated as another household in the community, and its income can be calculated the same as for any other household (e.g., Eq A.8 and accompanying equations). There are, however, some important differences. The production systems of community forestlands are generally similar to private land, except that no cereal production occurs since this requires clearing land of forest and possibly terracing. The community forest has two output markets instead of one, since some of the output can be sold to member households at the special community price $(P i c)$, and the remainder sold at farm gate prices $(P i s)$. The labor supply for the community forest comes from mandatory labor contributions from member households mentioned previously $(L c)$, and from hired labor. The main difference between production on community forest and private land is that government and community policies affect what kinds of production take place and how that production occurs. In particular, while communities in principle have control over the use of their forests, the government enforces restrictions on use to meet national or international policy objectives (e.g., meeting climate change commitments, reducing erosion). In one common policy, a proportion of community forest of land type $k$ may be restricted from any use $\left(G^{l} k\right)$. Depending on the policy, $G^{1} k$ can range from 0 (no restrictions) to 1 (all community forest land of type $k$ restricted from use). Another common policy is for the government to constrain production levels below maximum output $\left(G^{2} i\right)$. An example of this is the policy of restricting timber harvest to a proportion of the mean annual increment of the forest (MAI). Under normal forestry practices, sustainable management means harvesting an annual volume equal to the MAI. The 
value of $G^{2} i$ can range from 0 (no restriction on harvesting the MAI) to 1 (no harvesting). These policies mean that Eq. A1 needs to be modified for the effect of policies on community forest outputs (qc $i$ ).

$$
q_{i}^{c}=\sum_{k=1}^{K} \sum_{t=1}^{T}\left(R_{i t k} G_{i}^{2}\right)\left(a_{t k} \cdot G_{k}^{1}\right)
$$

The government policy can allow the community to manage the community forest on a lease basis to individual households. In this case the household manages the community forest land it leases like private land, subject to constraints on certain types of production. In return, the community receives a rental payment. This is similar to Eq A.7 for a household. 